\title{
Innovation networks in milpa production systems
}

\author{
Elizabeth Roldán-Suárez ${ }^{1}$ \\ Asael Islas-Moreno' \\ Julia Sánchez-Gómez ${ }^{1}$ \\ Roberto Rendón-Medel ${ }^{2 *}$
}

\begin{abstract}
Innovation is a process that is not only developed in educational and research institutions. In rural territories, agricultural producers are constantly innovating through the use of tacit or explicit knowledge. This knowledge comes from a variety of information sources, so producers interact with different actors. The aim of this paper is to analyze the relationship between the social interaction, innovation and yields obtained by milpa system producers in six municipalities of the Yucatán Peninsula, in order to propose alternative innovation management strategies that generate individual and collective well-being in the territories. In total, 149 direct interviews were conducted with milpa system producers and then analyzed using the Social Network Analysis methodological tool. Results indicate different network structures in the municipalities depending on their level of innovation, information exchange processes and productive parameters. The factors to be developed in these types of networks refer to increases in the density of their relationships, the diversity of information sources and the quality of the links expressed in improving their productivity.
\end{abstract}

Keywords: Extension, interaction, network typology.

\section{Redes de innovación en sistemas de producción de milpa}

\section{Resumen}

La innovación es un proceso que no solo se desarrolla en las instituciones de enseñanza e investigación. En los territorios rurales, los productores agrícolas constantemente se encuentran innovando a través del uso del conocimiento tácito o explícito. Este conocimiento proviene de una variedad de fuentes de información, por lo que los productores interaccionan con diversos actores. El objetivo del presente trabajo es analizar la relación entre la interacción social, la innovación y los rendimientos obtenidos por los productores del sistema milpa en seis municipios de la Península de Yucatán, con el fin de proponer estrategias alternativas de gestión de la innovación que genere bienestar individual y colectivo en los territorios. Se aplicaron 149 entrevistas directas a productores del sistema milpa, las cuales fueron analizadas mediante la herramienta metodológica Análisis de Redes Sociales. Los resultados señalan diferentes estructuras de redes en los municipios en función de su nivel de innovación, de sus procesos de intercambio de información y parámetros productivos. Los factores por desarrollar en estos tipos de redes refieren a incrementos en la densidad de sus relaciones, la diversidad de fuentes de información y la calidad de los vínculos expresados en la mejora de su productividad.

Palabras clave: Extensionismo, interacción, tipología de redes.

\footnotetext{
'Universidad Autónoma Chapingo. Doctorado en Problemas Económico-Agroindustriales del Centro de Investigaciones Económicas, Sociales y Tecnológicas de la Agroindustria y la Agricultura Mundial (CIESTAAM). Carretera México-Texcoco km 38.5, Chapingo, Texcoco Estado de México.

${ }^{2}$ Universidad Autónoma Chapingo. Centro de Investigaciones Económicas, Sociales y Tecnológicas de la Agroindustria y la Agricultura Mundial (CIESTAAM). Carretera México-Texcoco km 38.5, Chapingo, Texcoco Estado de México.

*Corresponding author: rendon.roberto@ciestaam.edu.mx
} 


\section{Introduction}

The role of innovation as an explanatory factor in regional development is widely recognized (Schumpeter, 1942; Nelson \& Winter, 1982; Dosi, Teece, \& Chytry, 1998; COTEC, 2001), with innovation being understood as any change (not only technological) based on scientific or empirical knowledge that produces value (not only economic) (Cotec, 2007).

Innovation is a process that agricultural producers constantly carry out in rural territories with the aim of promoting their individual and collective well-being (Aguilar, 2004). They make use of the knowledge they acquire through interaction with tacit and explicit sources of information (Nonaka \& Takeuchi, 1995), which involve a wide diversity of actors (Monge \& Hartwich, 2008; Klerkx, Aarts, \& Leeuwis, 2010), thus generating social capital.

The concept of social capital has been constructed to describe the set of resources that emanate from interaction. However, there is no consensus on a precise definition despite the efforts made by authors such as Bourdieu (1980), Coleman (1988) and Putnam (1995). Social capital is formed by different concepts that underline several aspects of social interaction such as trust, culture, community, norms and networks. Nevertheless, some questions remain unresolved, for example, how social capital is created and how it is transmitted. It is known that social and institutional contexts need to be considered in understanding development processes. Given the multi-conceptuality of the term, work in the field of social capital is complex, so the need remains to use less global, more precise and directly measurable concepts (Poder, 2011), among which that of innovation networks stands out.

Innovation networks are relational structures that allow access to information, inputs, infrastructure and institutions required to innovate and improve the conditions of territories (Radjou, 2004; Muñoz, Rendón, Aguilar, García, \& Altamirano, 2004; Monge \& Hartwich, 2008). In this respect, various empirical studies confirm a causal effect between social interaction, innovation and productivity in the agricultural sector (García, Aguilar, \& Bernal, 2011; Almaguer-Vargas \& Ayala-Garay, 2014; Vargas, Palacios, Camacho, Aguilar, \& Ocampo, 2015; RoldánSuárez, Rendón-Medel,\& Cadena-Iñiguez, 2016;

\section{Introducción}

El papel de la innovación como factor explicativo del desarrollo de las regiones es ampliamente reconocido (Schumpeter, 1942; Nelson \& Winter, 1982; Dosi, Teece, \& Chytry, 1998; COTEC, 2001); entendiendo por innovación, todo cambio (no solo tecnológico) basado en el conocimiento científico o empírico que produce valor (no solo económico) (Cotec, 2007).

La innovación es el proceso que los productores agrícolas realizan constantemente en los territorios rurales con el objetivo de promover su bienestar individual y colectivo (Aguilar, 2004). Estos hacen uso del conocimiento que adquieren a través de la interacción con fuentes tácitas y explícitas de información (Nonaka \& Takeuchi, 1995), que involucran a una amplia diversidad de actores (Monge \& Hartwich, 2008; Klerkx, Aarts, \& Leeuwis, 2010), generando así capital social.

El concepto de capital social se ha construido para describir el conjunto de recursos que emanan de la interacción. Sin embargo, no existe consenso de una definición precisa a pesar de los esfuerzos realizados por autores como Bourdieu (1980), Coleman (1988) y Putnam (1995). El capital social se forma por conceptos diferentes que subrayan varios aspectos de la interacción social como confianza, cultura, comunidad, normas y redes. No obstante, algunas cuestiones siguen sin resolverse, por ejemplo, cómo se crea el capital social y cómo se transmite. Se sabe que es necesario tomar en cuenta los contextos sociales e institucionales en la compresión de los procesos de desarrollo. Dada la multiconceptualidad del término, el trabajo en el campo de capital social es complejo, por lo que permanece la necesidad de utilizar conceptos menos globales, más precisos y directamente medibles (Poder, 2011), entre ellos destaca el concepto redes de innovación.

Las redes de innovación son estructuras relacionales que permiten el acceso a información, insumos, infraestructura e instituciones requeridas para innovar y mejorar las condiciones de los territorios (Radjou, 2004; Muñoz, Rendón, Aguilar, García, \& Altamirano, 2004; Monge \& Hartwich, 2008). Al respecto, diversos estudios empíricos confirman un efecto causal entre la interacción social, innovación y productividad en el sector agrícola 
Islas \& Rendón, 2019). In these studies, innovation acts as an intermediate variable, that is, innovation is driven by greater interaction among actors in the networks to subsequently generate greater productivity in production systems. As for the quality of interaction, there is evidence that producers who balance their interaction by turning to local and external sources are more likely to innovate and also to improve the results of their productive activity (Cofré-Bravo, Klerkx, \& Engler, 2019; Wójcik, JeziorskaBiel, \& Czapiewski, 2019). Similarly, trust among participants is a point to consider to identify barriers and precursor elements in innovation processes and productivity improvement (King, Fielke, Bayne, Klerkx, \& Nettle, 2019).

The so-called "milpa" production system is one of the most deeply-rooted activities in Mexico; it has been of great importance since before the arrival of the Spaniards (Terán, 2010). Some of the benefits of this system are: it is sustainable over time, since it does not deplete the resource base, it is compatible with biodiversity conservation and it allows peasant families to produce enough to feed themselves (Schwartz \& Corzo, 2015). This last aspect makes the milpa system be seen as a strategy to recover food sovereignty, nutritional security and control of environmental resources in various regions of the country (Gómez, 2013). According to Salazar and Magaña (2016), in the Yucatán peninsula, traditional agricultural production systems such as the milpa are of great importance and are practiced in Mayan communities. This influences access to food, as well as the generation of supplementary income from the sale of products and by-products.

In this context, the impetus for innovation through interaction in the milpa system becomes relevant. The aim of this paper is to analyze the causal relationship between social interaction, innovation and productivity obtained by milpa system producers in six municipalities of the Yucatán peninsula. For this purpose, the social structure, level of innovation and the yields of the producers in question are analyzed in order to propose alternative strategies for innovation management that are the basis for the generation of individual and collective well-being in these territories.
(García, Aguilar, \& Bernal, 2011; Almaguer-Vargas \& Ayala-Garay, 2014; Vargas, Palacios, Camacho, Aguilar, \& Ocampo, 2015; Roldán-Suárez, Rendón-Medel,\& Cadena-Iñiguez, 2016; Islas \& Rendón, 2019). En estos estudios la innovación funge como una variable intermedia, es decir, la innovación es impulsada por una mayor interacción entre los actores en las redes para posteriormente generar mayor productividad en los sistemas productivos. En cuanto a la calidad de la interacción, existe evidencia que los productores que equilibran su interacción acudiendo a fuentes locales y externas, muestran mayor propensión a innovar y también a mejorar los resultados de la actividad productiva (Cofré-Bravo, Klerkx, \& Engler, 2019; Wójcik, Jeziorska-Biel, \& Czapiewski, 2019). De igual manera, la confianza entre los participantes es un punto a considerar para identificar barreras y elementos precursores en los procesos de innovación y la mejora de la productividad (King, Fielke, Bayne, Klerkx, \& Nettle, 2019).

El sistema de producción denominado "milpa" es una de las actividades más arraigadas en México; tiene una gran importancia desde antes de la llegada de los españoles (Terán, 2010). Algunos de los beneficios de este sistema es la sostenibilidad a través del tiempo, ya que no agota la base de recursos, es compatible con la conservación de la biodiversidad y permite que las familias campesinas produzcan lo suficiente para alimentarse (Schwartz \& Corzo, 2015). Este último aspecto hace que el sistema milpa se visualice como una estrategia para recuperar la soberanía alimentaria, la seguridad nutricional y el control de los recursos ambientales de diversas regiones del país (Gómez, 2013) . De acuerdo con Salazar y Magaña (2016), en la península de Yucatán, los sistemas de producción agrícola tradicionales como la milpa, son de gran importancia y se practican en las comunidades mayas. Esto influye en el acceso a los alimentos, así como en la generación de ingresos complementarios por venta de productos y subproductos.

Bajo este contexto, el impulso de la innovación por medio de la interacción en el sistema milpa cobra relevancia. El objetivo del presente trabajo es analizar la relación causal entre interacción social, innovación y productividad obtenida por los productores del 


\section{Materials and methods}

\section{Study area and universe}

The research was carried out in six municipalities of the Yucatán Penninusla: Calakmul, Chikindzonot, José María Morelos, Maxcanú, Peto and Yaxcabá (Figure 1). Interviews were conducted with 149 milpa system producers selected through a sample aimed at beneficiaries of the government program: Sustainable Modernization of Conventional Agriculture (MasAgro), led by the International Maize and Wheat Improvement Center (CIMMYT), funded by the now Ministry of Agriculture and Rural Development (SADER).

\section{Information instrument and collection}

The applied survey was divided into two sections: in the first one, the identification of the producer and the production system were considered, with the requested data being: name, age, level of education, crop, varieties, planting density, yield, type of land, type of irrigation and use of machinery, sistema milpa en seis municipios de la península de Yucatán. Para tal propósito se analiza la estructura social, el nivel de innovación y los rendimientos de los productores en cuestión, con el fin de proponer estrategias alternativas de gestión de la innovación que sean la base para la generación de bienestar individual y colectivo en dichos territorios.

\section{Materiales y métodos}

Áreay universo de estudio

La investigación se llevó a cabo en seis municipios de la península de Yucatán: Calakmul, Chikindzonot, José María Morelos, Maxcanú, Peto y Yaxcabá (Figura 1). Se entrevistaron a 149 productores del sistema milpa seleccionados a través de un muestreo dirigido a beneficiarios del programa gubernamental: Modernización Sustentable de la Agricultura Convencional (MasAgro), liderado por el Centro de Mejoramiento de Maíz y Trigo (CIMMYT), financiado por la ahora Secretaría de Agricultura y Desarrollo Rural (SADER).

Figure 1. Location of the municipalities considered in the study.

Figura 1. Localización de los municipios considerados en el estudio.

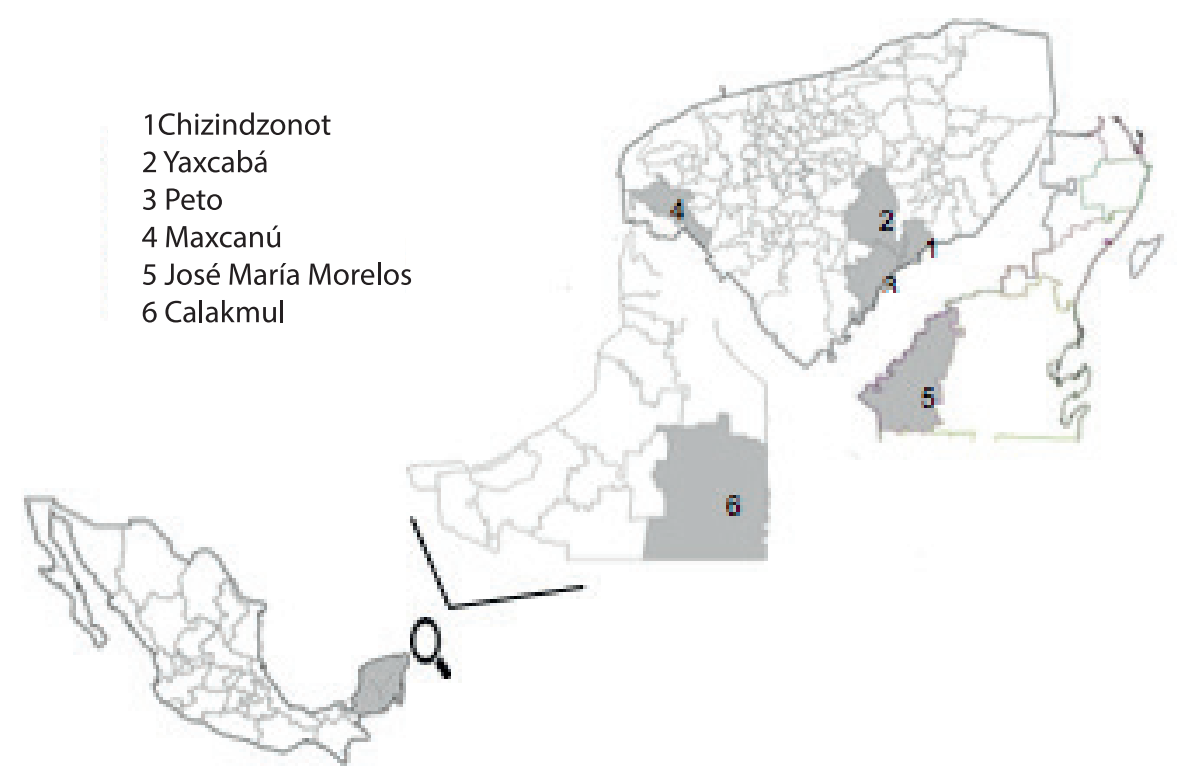

Source: Author-made

Fuente: Elaboración propia. 
among others; the second section corresponded to the type of innovations applied by the producers and their sources of technical information. The survey was carried out by the technical staff of Hub Peninsula Yucatán-MasAgro from June to August 2016.

The catalog proposed by Rendón, Aguilar, Altamirano, \& Muñoz (2007) was used to capture the relational information; in it, an identifier is assigned to each actor according to its function: Rural Company (RC), Referred Rural Company (ReC), Family (FAM), Teaching and Research Institution (TI), Government Institution (GI), Producer Organization (PO), Genetic Provider (GP), Equipment Provider (EP), Final Client $(F C)$, Financial Services Provider (FP), Intermediary Client (IC), Multiple Function (MF), Collection Center or Agribusiness (CC), Professional Services Provider (PSP), Input Supplier (IP) and Non-Producer (NP).

\section{Indicators used in research}

Social Network Analysis (SNA) is based on the premise that social actors are independent and their linkage has important consequences for each of them (Freeman, 2004). This analysis considers the following network indicators, and their calculation was made in the UCINET program (Borgatti, Everett, \& Freeman, 2002), version $6.288^{\oplus}$.

Density: it is the ratio of all existing relationships over all possible relationships of a network (Wasserman \& Faust, 1994). It is calculated using the following formula:

$D=\frac{I}{N(N-1)} * 100$

Where $\mathrm{D}$ is the density of a network expressed as a percentage, $L$ denotes existing relationships and $N$ the number of actors in the network.

Access to information factor: it measures the level of access that each respondent has to the different actors that exist in the network in order to acquire information. It is based on what was proposed by Corsaro, Cantú, \& Tunisini (2012), who state that interaction with the diversity of actors that exist in an innovation network allows access to information on new ways of production, obtaining services and external support, so this factor is divided into three types according to information sources.
Instrumento y colecta de información

La encuesta aplicada se estructuró en dos apartados: en el primero, se consideró la identificación del productor y el sistema de producción, los datos solicitados fueron: nombre, edad, nivel de escolaridad, cultivo, variedades, densidad de siembra, rendimiento, tipo de tierra, tipo de riego y uso de maquinaria, entre otros; el segundo apartado correspondió al tipo de innovaciones que aplicaban los productores y sus fuentes de información técnica. La encuesta se realizó por el personal técnico del Hub Península Yucatán-MasAgro, durante los meses de junio a agosto de 2016.

Para la captura de la información relacional se empleó el catálogo propuesto por Rendón, Aguilar, Altamirano, \& Muñoz (2007), en el cual se asigna un identificador a cada actor según su función: Empresa Rural (ER), Empresa Rural Referida (ERe), Familiar (FAM), Institución de Enseñanza e Investigación (IE), Institución Gubernamental (IG), Organización de Productores (OR), Proveedor de Genética $(P G)$, Proveedor de Equipo (PE), Cliente Final (CF), Proveedor de Servicios Financieros (PF), Cliente Intermediario $(\mathrm{Cl})$, Función Múltiple (FM), Centro de Acopio o Agroindustria (CA), Prestador de Servicios Profesionales (PSP), Proveedor de Insumos (PI) y No Productor (NP).

\section{Indicadores utilizados en la investigación}

El Análisis de Redes Sociales (ARS) se basa en la premisa de que los actores sociales son independientes y su vinculación tiene consecuencias importantes para cada uno de ellos (Freeman, 2004). Este análisis considera los siguientes indicadores de la red, y su cálculo se realizó en el programa UCINET (Borgatti, Everett, \& Freeman, 2002), versión 6.288 ${ }^{\circledR}$.

Densidad: es la proporción de todas las relaciones existentes con respecto a las relaciones posibles de una red (Wasserman \& Faust, 1994). Se calcula empleando la siguiente fórmula:

$D=\frac{I}{N(N-1)} * 100$

Donde $\mathrm{D}$ es la densidad de una red expresada en porcentaje, $\mathrm{L}$ denota las relaciones existentes y $\mathrm{N}$ el número de actores en la red. 
The total access factor $\left(F_{t}\right)$ refers to the level of access to information held by the actors surveyed, considering the totality of the different actors in the network. It is calculated by dividing the number of total actors in the network $(\mathrm{N})$ minus the surveyed actors (ER) by the number of respondents (ER).

$F_{t}=\frac{N-E R}{E R}$

The internal access factor $\left(F_{i}\right)$ measures the level of access that each respondent has to the information of the actors in their local environment, mainly other producers and family members. It is the sum of the total number of local actors, in this case those with the keys ReC, FAM and PO, divided by the number of surveyed actors (ER).

$F_{i}=\frac{(R e C+F A M+P O)}{E R}$

The external access factor $\left(\mathrm{F}_{\mathrm{e}}\right)$ refers to the information that the respondent acquires from external sources or actors such as suppliers of goods and services, clients and institutions. This factor is the sum of the total number of actors not belonging to the producer's local environment, in this case PSP, IP, $\mathrm{IC}, \mathrm{Gl}, \mathrm{MF}, \mathrm{FP}, \mathrm{TI}, \mathrm{FC}, \mathrm{GP}$ and $\mathrm{EP}$, divided by the number of surveyed actors (ER).

$F_{e}=\frac{(P S P+I P+I C+C C+G i+M f+F P+T I+F C+G P+E P)}{E R}$

Innovation Adoption Index (InAI): it is the innovative ability of the producer (Muñoz, Aguilar, Rendón, \& Altamirano, 2007), calculated as the number of practices that the producer carries out at a given time over the number of total practices defined in a catalogue:

$\ln A I_{i}=\frac{\sum_{j=1}^{n} I n n o v_{j n}}{n}$

Where: $\ln \mathrm{Al}_{\mathrm{i}}$ is the innovation adoption index of the $i^{\text {th }}$ producer. Innov $_{\text {in }}$ refers to the presence of the $j^{- \text {th }}$ innovation of $\mathbf{n}$ innovations and $\mathbf{n}$ is the total number of innovations. For this case, the calculation considered
Factor de acceso a la información: mide el nivel de acceso que cada encuestado tiene hacia los distintos actores que existen en la red para adquirir información. Se basa en lo planteado por Corsaro, Cantú, \& Tunisini (2012), quienes mencionan que la interacción con la diversidad de actores que existen en una red de innovación, permite el acceso a información sobre nuevas maneras de producción, la obtención de servicios y el soporte externo, por lo que este factor se divide en tres tipos según las fuentes de información.

El factor de acceso total $\left(\mathbf{F}_{\mathbf{t}}\right)$ refiere al nivel de acceso a la información que poseen los actores encuestados, considerando la totalidad de los distintos actores en la red. Se calcula dividiendo el número de actores totales en la red $(\mathrm{N})$ menos los actores encuestados (ER) entre el número de encuestados (ER).

$F_{t}=\frac{N-E R}{E R}$

El factor de acceso interno $\left(\mathrm{F}_{\mathrm{i}}\right)$ mide el nivel de acceso que cada encuestado tiene a la información de los actores de su entorno local, principalmente otros productores y familiares. Es la suma del número total de actores locales, en este caso, los que tienen las claves ERe, FAM y OR, divididos entre el número de productores encuestados (ER).

$F_{i}=\frac{(\operatorname{Re} C+F A M+P O)}{E R}$

El factor acceso externo $\left(\mathrm{F}_{\mathrm{e}}\right)$ se refiere a la información que el encuestado adquiere de fuentes o actores externos como proveedores de bienes y servicios, clientes e instituciones. Este factor es la suma del número total de actores que no pertenecen al entorno local del productor, en este caso PSP, $\mathrm{PI}, \mathrm{Cl}$, $C A, I G, F M, P F, I E, C F, P G$ y $P E$, dividido entre el número de actores encuestados (ER).

$F_{e}=\frac{(P S P+P I+C I+C A+I G+F M+P F+I E+C F+P G+P E)}{E R}$

Índice de Adopción de Innovaciones (InAl): es la capacidad innovadora del productor (Muñoz, 
38 innovations classified in eight categories: agronomic management, seeds, nutrition, plant health, post-harvest technologies, market and financing, organization and administration, and climate effectiveness, which should be applied in the milpa production system to improve its yield.

\section{Information analysis}

Statistical analysis of the data was performed in SAS statistical package v. 9.0. ANOVA analysis was used to observe the differences between the means of the variables age, schooling, planted area, previous cycle yield and the innovation level of the producer according to the municipality in which it was located; the adoption of innovations by category and the overall average index were compared.

Based on the ratio between external and internal links and the density indicator, a network typology was constructed (Figure 2). The desirable outcome is a value close to unity, because it represents a balance between the number of local and external information sources, and a density close to $100 \%$, that is, that all possible relationships in the network are consolidated. In order to generate the quadrants and classify the types of networks in the municipalities, the average density value of the networks in the six municipalities $(2.40 \%)$ and the value of one for the
Aguilar, Rendón, \& Altamirano, 2007), se calcula como el número de prácticas que el productor realiza en un determinado momento sobre el número de prácticas totales definidas en un catálogo:

$\ln A I_{i}=\frac{\sum_{j=1}^{n} \operatorname{lnnov} v_{j n}}{n}$

Donde: $\ln \mathrm{Al}_{\mathrm{i}}$ es el índice de adopción de innovaciones del iésimo productor. Innov $_{\text {in }}$ se refiere a la presencia de la j-ésima innovación de $\mathbf{n}$ innovaciones y $\mathbf{n}$ es número total de innovaciones. Para este caso, el cálculo consideró 38 innovaciones clasificadas en ocho categorías: manejo agronómico, semillas, nutrición, fitosanidad, tecnologías poscosecha, mercado y financiamiento, organización y administración $y$, efecto climatológico, las cuales deberían aplicarse en el sistema de producción milpa para tener un mejor desempeño en la actividad.

\section{Análisis de la información}

El análisis estadístico de los datos se realizó en el paquete estadístico SAS v. 9.0. El análisis ANOVA se utilizó para observar las diferencias entre las medias de las variables edad, escolaridad, superficie sembrada, rendimiento ciclo anterior y el nivel de

Figure 2. Proposal for the formation of network typology.

Figura 2. Propuesta para la conformación de tipología de redes.

\begin{tabular}{|c|c|c|c|}
\hline \multirow{3}{*}{$\begin{array}{l}\text { Internal factor/ } \\
\text { External factor / } \\
\text { Factor interno/ } \\
\text { Factor externo }\end{array}$} & $\begin{array}{l}\text { Greater than } 1 \text { / } \\
\text { Mayor a } 1\end{array}$ & $\begin{array}{l}\text { Low-density network dominated } \\
\text { by locals / } \\
\text { Red poco densa dominada } \\
\text { por locales }\end{array}$ & $\begin{array}{l}\text { Dense network dominated } \\
\text { by locals / } \\
\text { Red densa dominada por locales }\end{array}$ \\
\hline & $\begin{array}{l}\text { Equal to } 1 \text { / } \\
\text { Igual a } 1\end{array}$ & $\begin{array}{l}\text { Balanced low-density network / } \\
\text { Red poco densa equilibrada }\end{array}$ & $\begin{array}{l}\text { Balanced dense network / } \\
\text { Red densa equilibrada }\end{array}$ \\
\hline & $\begin{array}{l}\text { Less than } 1 \text { / } \\
\text { Menor a } 1\end{array}$ & $\begin{array}{l}\text { Low-density network dominated } \\
\text { by outsiders / } \\
\text { Red poco densa dominada por } \\
\text { foráneos }\end{array}$ & $\begin{array}{l}\text { Dense network dominated by } \\
\text { outsiders / } \\
\text { Red densa dominada por } \\
\text { foráneos }\end{array}$ \\
\hline & & Low density / Baja densidad & High density / Alta densidad \\
\hline & & \multicolumn{2}{|c|}{ Network density / Densidad de la red } \\
\hline
\end{tabular}

Source: Author-made

Fuente: Elaboración propia. 
case of the ratio between internal factor and external factor were considered. The proposed typology was carried out in order to develop alternative intervention strategies for each municipality.

The municipalities analyzed were also classified according to their InAl and yield vs. the ratio between the internal and external factors of the respondents. For this, the average value of the InAl and the yield of the six municipalities were taken as a reference to establish quadrants. The association between the network, innovation and yield indicators was determined using Pearson's correlation tests.

\section{Results and discussion}

Characteristics of the producer and the production unit The producers interviewed in the six municipalities are characterized by their advanced age, low level of schooling and small areas planted with the milpa system (Table 1). Salazar and Magaña (2016) state that these conditions could represent a limitation for the optimal use of the production system. However, significant differences in schooling, planted area and yield were observed among municipalities. In the first variable, Calakmul, Chikindzonot and Peto stand out; their means showed statistically significant differences with the other three municipalities. innovación del productor según el municipio en el que se localizó, se comparó la adopción de las innovaciones por categoría y el índice promedio general.

A partir de la razón entre vínculos externos e internos y el indicador de densidad, se construyó una tipología de redes (Figura 2). Lo deseable debe presentar un valor cercano a la unidad, debido a que representa un equilibrio entre la cantidad de fuentes de información local y externa, y una densidad cercana al $100 \%$, es decir, que se consolidan todas las relaciones posibles en la red. Para generar los cuadrantes y clasificar los tipos de redes de los municipios, se consideró el valor promedio de la densidad de las redes de los seis municipios (2.40\%), y el valor de uno para el caso de la razón entre factor interno y factor externo. La tipología propuesta se realizó con el fin de desarrollar estrategias de intervención alternativas para cada municipio.

Los municipios analizados también se clasificaron según su InAl y rendimiento vs la razón entre el factor interno y externo de los encuestados. Para ello, se tomó el valor promedio del InAl y el rendimiento de los seis municipios como referencia para establecer cuadrantes. La asociación entre los indicadores de las redes, innovación y rendimiento se determinó con pruebas de correlación de Pearson.

Table 1. Characteristics of the producer and production unit by municipality.

Cuadro 1. Características del productor y de la unidad de producción por municipio.

\begin{tabular}{|c|c|c|c|c|c|}
\hline $\begin{array}{c}\text { Municipality / } \\
\text { Municipio }\end{array}$ & $\mathbf{N}$ & $\begin{array}{c}\text { Age } \\
\text { (years) / } \\
\text { Edad } \\
\text { (años) }\end{array}$ & $\begin{array}{l}\text { Schooling } \\
\text { (years) / } \\
\text { Escolaridad } \\
\text { (años) }\end{array}$ & $\begin{array}{c}\text { Planted area } \\
\text { (ha) / } \\
\text { Superficie } \\
\text { sembrada } \\
\text { (ha) }\end{array}$ & $\begin{array}{c}\text { Previous cycle } \\
\text { yield } \\
\left(t \cdot h a^{-1}\right) / \\
\text { Rendimiento } \\
\text { ciclo anterior } \\
\text { (t.ha-1) }\end{array}$ \\
\hline Calakmul & 24 & $48 \pm 3^{a}$ & $6.46 \pm .53^{a}$ & $0.40 \pm 0^{c}$ & $0.75 \pm 0.19^{a b}$ \\
\hline Chikindzonot & 25 & $50 \pm 3^{a}$ & $5.64 \pm .71^{a}$ & $2.52 \pm .25^{a}$ & $0.48 \pm .03^{b c}$ \\
\hline $\begin{array}{c}\text { José María } \\
\text { Morelos }\end{array}$ & 25 & $57 \pm 2^{a}$ & $2.0 \pm .43^{b}$ & $1.08 \pm .08^{b c}$ & $0.62 \pm .13^{\mathrm{ab}}$ \\
\hline Maxcanú & 25 & $58 \pm 2^{a}$ & $4.20 \pm .32^{\mathrm{ab}}$ & $1.01 \pm .09^{b c}$ & $0.91 \pm .02^{\mathrm{a}}$ \\
\hline Peto & 25 & $51 \pm 4^{a}$ & $4.68 \pm .77^{a}$ & $1.56 \pm .13^{b}$ & $0.20 \pm .02^{c}$ \\
\hline Yaxcabá & 25 & $60 \pm 3^{a}$ & $4.20 \pm .46^{\mathrm{ab}}$ & $2.70 \pm .29^{a}$ & $0.47 \pm .05^{\mathrm{bc}}$ \\
\hline
\end{tabular}

*Means with a different literal in the superindex in the same column indicate statistically significant differences $(P<0.05)$. Source: Author-made with field information (2016).

*Medias con diferente literal en el súper índice en la misma columna indica diferencias estadísticamente significativas $(P<0.05)$.

Fuente: Elaboración propia con información de campo (2016). 
Regarding planted area, Chikindzonot and Yaxcabá have a higher and different average than the others. In relation to the yield obtained, the Maxcanú producers had the highest average yield, contrary to the municipality of Peto, which had the lowest yield. In general, the yields obtained by the producers in the area are low compared to those described by Schwartz and Corzo (2015), who report an average yield of 1.29 thha $^{-1}$ in Yucatán (Mexico) and Petén (Guatemala). Consequently, the desired food sovereignty in the municipalities studied is compromised.

\section{Degree of adoption of innovations by milpa system} producers

The municipality that had the highest average InAI was Maxcanú, with a value statistically different from that of the other municipalities, except José María Morelos and Chikindzonot which followed in order of importance. The innovation categories with the highest number of adoptive producers in the municipalities were: seeds, climate effectiveness and post-harvest technologies. On the other hand, the categories with the lowest degree of adoption were those related to market and financing and organization and administration, so they present a greater area of management opportunity and could benefit from the usefulness of the product.

\section{The producer innovation network and access to information on innovations}

The ratio between the internal and external factors makes it possible to describe the level of balance that exists with respect to the information source actors available in the network. The presence of both internal and external agents favors a better linkage between producers in the network (Sánchez, Rendón, Díaz, \& Sonder, 2016). Just as a greater density in the network indicates the establishment of a greater number of relationships among actors (Table 3), and according to Radjou (2004), greater interaction with diverse agents facilitates access to knowledge and promotes adoption of innovations.

Figure 3 shows the position of the municipalities studied in relation to the previous indicators and they are classified according to the proposed network typology. In this sense, the municipality of José

\section{Resultados y discusión}

\section{Características del productory de la unidad de producción}

Los productores entrevistados en los seis municipios se caracterizan por ser de edad avanzada, con bajo nivel de escolaridad y por tener pequeñas superficies sembradas con el sistema milpa (Cuadro 1). Salazar y Magaña (2016) mencionan que estas condiciones podrían representar una limitante para el óptimo aprovechamiento del sistema de producción. No obstante, entre municipios se observaron diferencias significativas en escolaridad, superficie sembrada y rendimiento. En la primera variable destacan Calakmul, Chikindzonot y Peto, sus medias presentaron diferencias estadísticamente significativas con los otros tres municipios. Respecto a la superficie sembrada, Chikindzonot y Yaxcabá tienen un promedio mayor y diferente a los demás. Con relación al rendimiento obtenido, los productores de Maxcanú presentaron el mayor rendimiento promedio, caso contrario al municipio de Peto, que tuvo el menor rendimiento. En general en la zona los rendimientos obtenidos por los productores son bajos en comparación con los descritos por Schwartz y Corzo (2015), quienes reportan un rendimiento promedio de 1.29 tha ${ }^{-1}$ en Yucatán (México) y Petén (Guatemala). En consecuencia, la deseada soberanía alimentaria en los municipios estudiados se ve comprometida.

\section{Grado de adopción de innovaciones por los}

productores del sistema milpa

El municipio que presentó el mayor InAl promedio fue Maxcanú, valor estadísticamente diferente al de los demás municipios, excepto José María Morelos y Chikindzonot que le siguieron en orden de importancia. Las categorías de las innovaciones con un mayor número de productores adoptadores en los municipios fueron: semillas, efectos climatológicos y tecnologías poscosecha. Por otra parte, las categorías con un menor grado de adopción fueron las relacionadas con mercado y financiamiento $y$ organización y administración, por lo que presentan una mayor área de oportunidad de gestión y podrían beneficiar a la utilidad del producto. 
Table 3. Descriptive statistics of the network indicators analyzed. Cuadro 3. Estadística descriptiva de los indicadores de la red analizados.

\begin{tabular}{cccccc}
\hline $\begin{array}{c}\text { Indicator / } \\
\text { Indicador }\end{array}$ & $\mathbf{N}$ & $\begin{array}{c}\text { Minimum / } \\
\text { Mínimo }\end{array}$ & $\begin{array}{c}\text { Maximum / } \\
\text { Máximo }\end{array}$ & $\begin{array}{c}\text { Mean / } \\
\text { Media }\end{array}$ & $\begin{array}{c}\text { Standard } \\
\text { deviation / } \\
\text { Desviación } \\
\text { estándar }\end{array}$ \\
\hline $\begin{array}{c}\text { Density / } \\
\text { Densidad }\end{array}$ & 6 & 1.69 & 3.69 & 2.40 & 0.79 \\
$\begin{array}{c}\text { Total factor / } \\
\text { Factor total }\end{array}$ & 6 & 0.80 & 1.88 & 1.55 & 0.44 \\
$\begin{array}{c}\text { Internal factor / } \\
\text { Factor interno }\end{array}$ & 6 & 0.42 & 1.72 & 1.04 & 0.51 \\
$\begin{array}{c}\text { External factor / } \\
\text { Factor externo }\end{array}$ & 6 & 0.16 & 0.83 & 0.51 & 0.25 \\
\hline
\end{tabular}

Source: author-made with field information (2016).

Fuente: elaboración propia con información de campo (2016).

Figure 3. Position of the municipalities with respect to the proposed network typology.

Figura 3. Posición de los municipios con respecto a la tipología de redes propuesta.

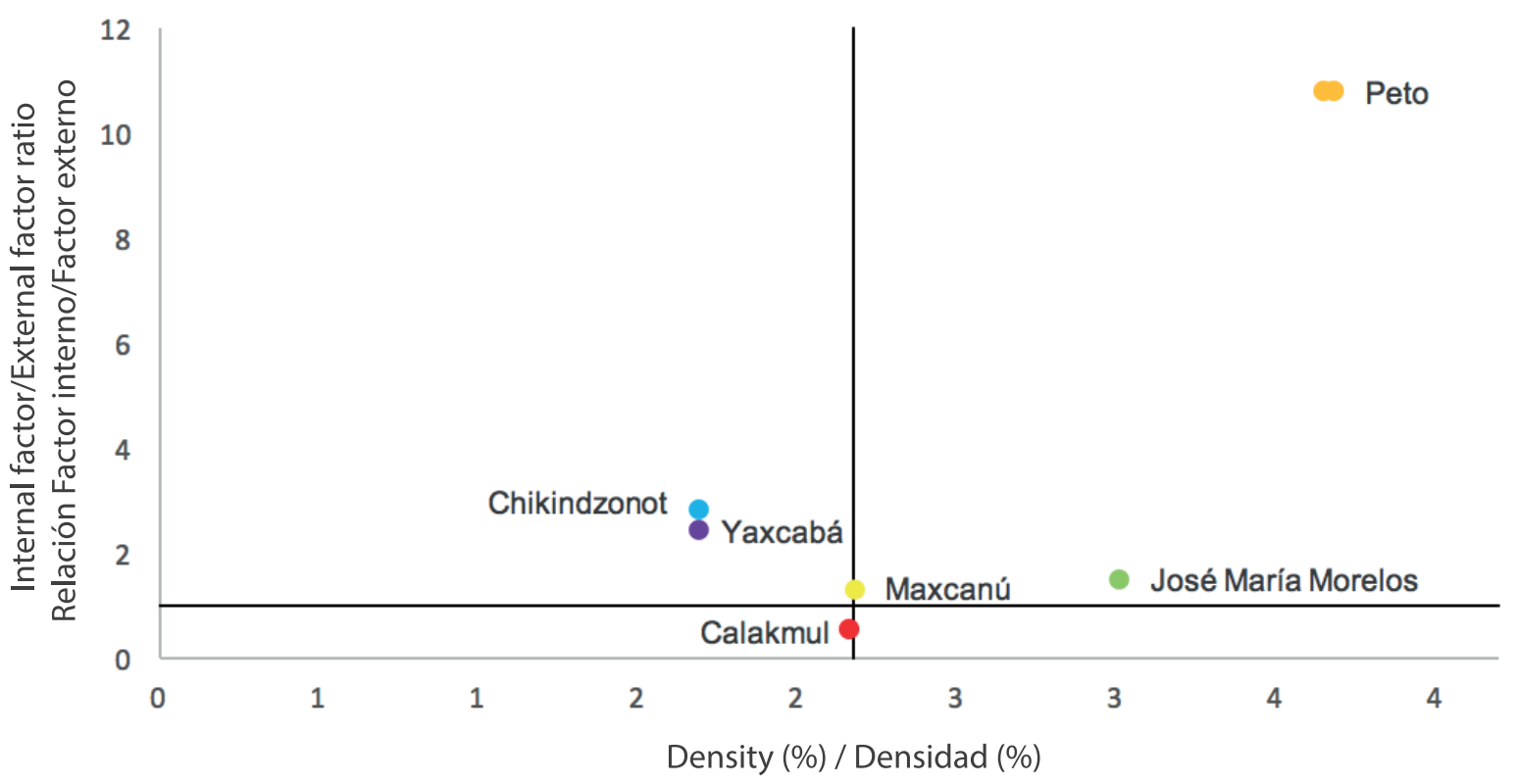

Source: Author-made with field information (2016).

Fuente: Elaboración propia con información de campo (2016). 
María Morelos is better positioned and presents the characteristics closest to a balanced dense network, being the network with a density higher than the average and with the greatest balance between its internal and external links. Therefore, Coleman (1988) states that the densest networks facilitate trust and norms among the actors.

In contrast, the municipalities of Calakmul and Maxcanú are located as balanced low-density networks, Chikindzonot and Yaxcabá are networks that are not very dense and dominated by local actors and Peto is characterized by being a dense network dominated by local actors.

As already noted, the municipalities of José María Morelos and Maxcanú showed a greater balance in the number of internal and external actors and were also in a better position with respect to $\operatorname{InAl}$ (Figure 4). For this reason, it could be argued that greater adoption of innovations is related to a balance in the access to information factors of the producers in each municipality. Other studies, such as that of Cofré-Bravo, Klerkx, and Engler (2019), have found that constant innovation is a trait of producers who show complete ambidexterity in the management of their knowledge sources; that is,
La red de innovación de los productores y el acceso a la información sobre las innovaciones

La razón entre el factor interno y externo permite describir el nivel de equilibrio que existe respecto a los actores fuentes de información disponibles en la red. Tanto la presencia de agentes internos como externos favorece una mejor vinculación de los productores en la red (Sánchez, Rendón, Díaz, \& Sonder, 2016). Al igual que una mayor densidad en la red indica el establecimiento de un mayor número de relaciones entre los actores (Cuadro 3), y de acuerdo con Radjou (2004), una mayor interacción con diversos agentes facilita el acceso al conocimiento y promueve la adopción de innovaciones.

En la Figura 3 se observa la posición de los municipios estudiados en relación con los indicadores anteriores y se clasifican de acuerdo con la tipología de redes propuesta. En este sentido, el municipio José María Morelos se encuentra mejor posicionado y presenta las características más cercanas a una red densa equilibrada, siendo la red con la mayor densidad que el promedio $y$, con mayor equilibrio entre sus vínculos internos y externos. Por lo tanto, Coleman (1988) hace referencia que las redes más densas facilitan la confianza y las normas entre los actores.

Figure 4. Position of the municipalities with respect to the Innovation Adoption Index.

Figura 4. Posición de los municipios con respecto al Índice de Adopción de Innovaciones.

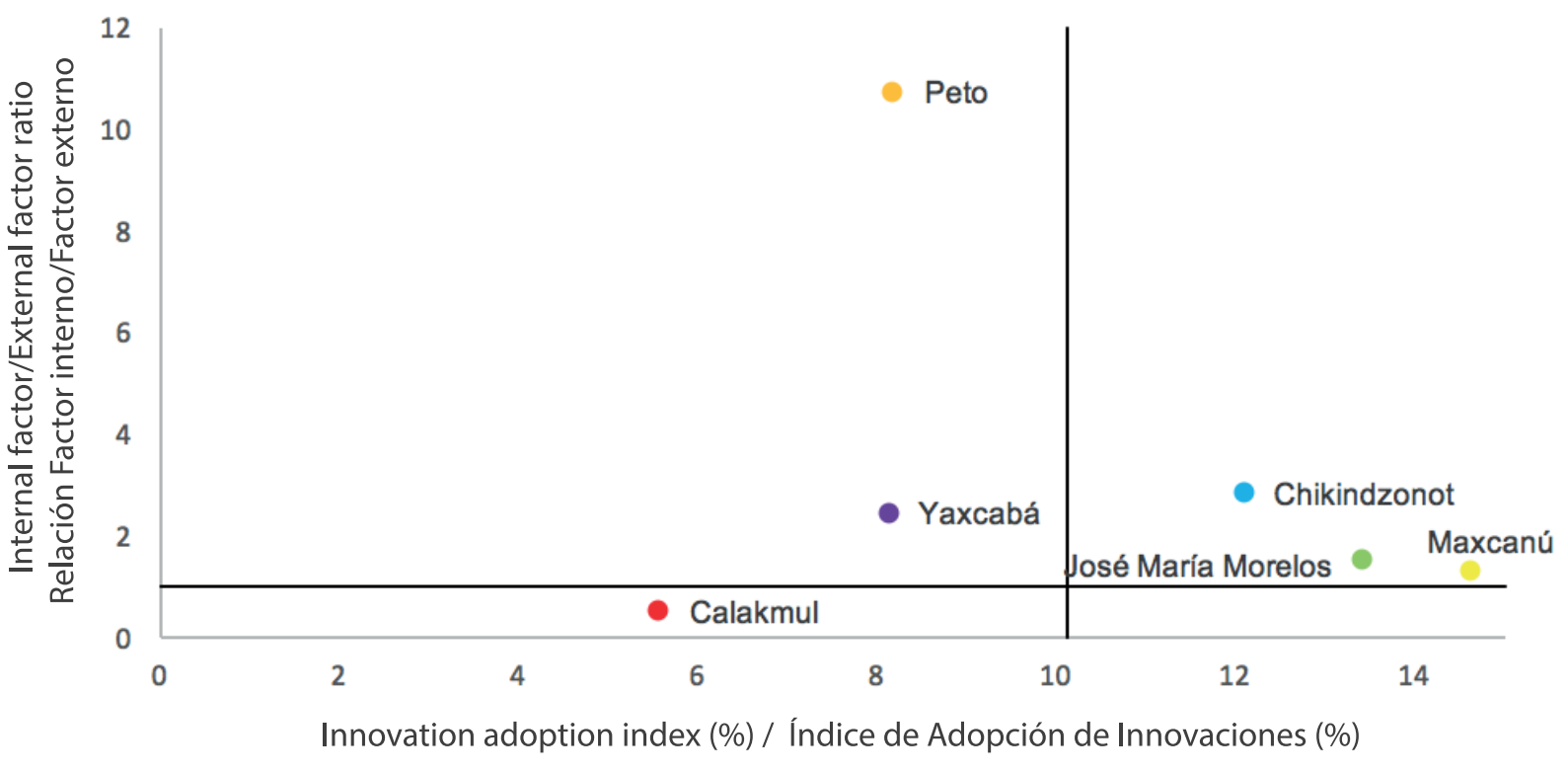

Source: Author-made with field information (2016).

Fuente: Elaboración propia con información de campo (2016). 
they are able to navigate in plural systems and create a balance between external links with institutions and advisors, and local links with family, peer producers and workers. According to Corsaro, Cantú, \& Tunisini (2012), the interaction among a diversity of actors allows obtaining information on new ways of production as well as support services and external support. In addition, Sánchez et al. (2016) state that local agents serve as social support and boost innovation within the system, while external agents provide incentives, financing and necessary resources for production. For their part, Wójcik et al. (2019) find that formal knowledge provided predominantly by external sources is absorbed with greater difficulty by producers, whereas informal knowledge provided by local actors is transferred without many obstacles due to spatial, cultural and family proximity. Therefore, managing the local space is key to transferring and stabilizing knowledge; however, the changes with the greatest potential in agriculture will depend on the ability to adapt to external conditions.

The balance in access to information factors was found to be associated with a higher InAl level and also with a higher yield obtained in the milpa system in 2015 (Figure 5). The municipalities of José María Morelos, Calakmul and Maxcanú showed the greatest balance in terms of availability of internal and external sources. José María Morelos and Maxcanú are the most innovative and the three are the ones that obtained the best yields.

\section{Relationship between networks, innovation and yields} obtained in the milpa system

This study found a direct and significant association $(P<0.01, P<0.05)$ between the innovation categories: agronomic management, plant health, nutrition, and yield. This is explained by the fact that the innovations of the three categories directly influence the production unit's productivity. Otherwise, the categories are: post-harvest technologies, market and financing, organization and management, and climate effectiveness (Table 4). However, these latter categories are relevant for the producer because they relate to the profitability and income obtained from the sale of the product. On the other hand, a direct and significant association $(P<0.01)$ was found
En contraste, los municipios Calakmul y Maxcanú se ubican como redes poco densas y equilibradas, Chikindzonot y Yaxcabá son redes poco densas y dominadas por actores locales y Peto se caracteriza por ser una red densa dominada por actores locales.

Como ya se observó, los municipios de José María Morelos y Maxcanú presentaron un mayor equilibrio en la cantidad de actores internos y externos, y también se ubicaron en una mejor posición respecto al InAl (Figura 4). Por tal motivo, se podría argumentar que una mayor adopción de innovaciones está relacionada con un equilibrio en los factores de acceso a información de los productores de cada municipio. En otros estudios como el de CofréBravo, Klerkx, y Engler (2019) han encontrado que la innovación constante es un rasgo de productores que muestran una ambidiestralidad completa en el manejo de sus fuentes de conocimiento; es decir, son capaces de navegar en sistemas plurales y crear un equilibrio entre vínculos externos con instituciones y asesores, y vínculos locales con familia, productores pares y trabajadores. De acuerdo con Corsaro, Cantú, \& Tunisini (2012), la interacción entre una diversidad de actores permite la obtención de información sobre nuevas maneras de producción así como el apoyo de servicios y soporte externo. Además, Sánchez et al., (2016) mencionan que los agentes locales sirven como apoyo social e impulso a la innovación dentro del sistema, mientras que los agentes externos brindan incentivos, financiamiento y recursos necesarios para la producción. Por su parte, Wójcik et al., (2019) encuentran que el conocimiento formal provisto predominantemente por fuentes externas es absorbido con mayor dificultad por los productores, en cambio, el conocimiento informal proporcionado por actores locales se transfiere sin muchos obstáculos debido a la proximidad espacial, cultural y familiar. Por tanto, gestionar el espacio local es clave para transferir y estabilizar el conocimiento, sin embargo, los cambios de mayor potencialidad en la agricultura dependerán de la capacidad de adaptación a las condiciones externas.

El equilibrio en los factores de acceso a la información se encontró asociado con un mayor nivel de InAl y, también con un mayor rendimiento obtenido en el sistema milpa en el año 2015 (Figura 5). Los municipios de José María Morelos, Calakmul y 
Figure 5. Position of the municipalities under study with respect to the yield obtained in 2015 and relationship between factors.

Figura 5. Posición de los municipios de estudio con respecto al rendimiento obtenido en el año 2015 y relación entre factores.

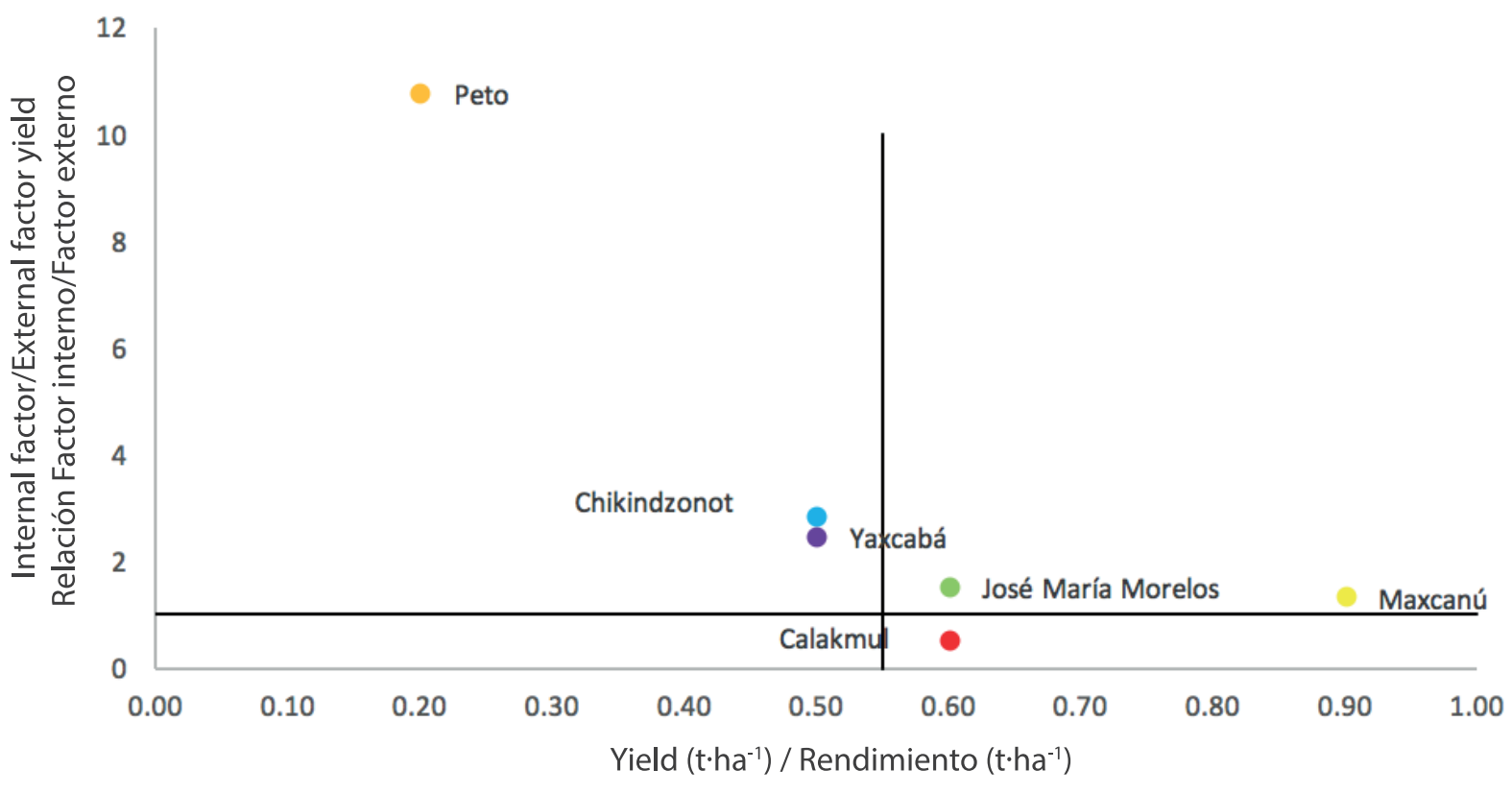

Source: Author-made with field information (2016).

Fuente: Elaboración propia con información de campo (2016).

between the categories agronomic management, nutrition and plant health with the external factor, which is explained by the fact that these categories require knowledge of an explicit type (Nonaka \& Takeuchi, 1995), that is, specialized knowledge, normally provided by technical advisors, teaching and research institutions, and others. With respect to the internal factor, a direct and significant association $(P<0.01)$ was found with the categories of seeds, postharvest technologies and climate effectiveness, which could be explained by the fact the categories carry with them tacit knowledge (Nonaka and Takeuchi, 1995), a knowledge that has been passed down from generation to generation (Table 4).

Although the present study focuses on the analysis of innovation networks, the discussion presented herein cannot neglect other dimensions associated with the concept of social capital, particularly the trust expressed in different facets, since it is a variable that influences innovation processes, in which those involved, the available external resources
Maxcanú son los que mostraron mayor equilibrio en cuanto a su disponibilidad de fuentes internas y externas. José María Morelos y Maxcanú son los más innovadores y los tres son los que obtuvieron mejores rendimientos.

\section{Relación entre redes, innovación y rendimientos} obtenidos en el sistema milpa

En este estudio se encontró una asociación directa y significativa $(P<0.01, P<0.05)$ entre las categorías de innovación: manejo agronómico, fitosanidad, nutrición, y rendimiento. Esto se explica porque las innovaciones de las tres categorías influyen directamente en la productividad de la unidad de producción. Caso contrario lo son las categorías: tecnologías poscosecha, mercado y financiamiento, organización y administración, y efecto climatológico (Cuadro 4). Sin embargo, estas últimas categorías son relevantes para el productor porque se relacionan con la rentabilidad e ingresos obtenidos por la venta del producto. Por otra parte, se encontró 
Table 4. Pearson's correlation between variables and level of significance.

Cuadro 4. Correlación de Pearson entre variables y nivel de significancia.

\begin{tabular}{|c|c|c|c|c|}
\hline $\begin{array}{l}\text { Innovation category / } \\
\text { Categoría de innovación }\end{array}$ & $\begin{array}{c}\text { Yield / } \\
\text { Rendimiento }\end{array}$ & $\begin{array}{c}\text { Internal } \\
\text { factor / } \\
\text { Factor } \\
\text { interno }\end{array}$ & $\begin{array}{l}\text { External factor } / \\
\text { Factor externo }\end{array}$ & $\begin{array}{l}\text { Density / } \\
\text { Densidad }\end{array}$ \\
\hline $\begin{array}{l}\text { Agronomic management / } \\
\text { Manejo agronómico }\end{array}$ & $0.34^{* *}$ & 0.03 & $0.31^{* *}$ & $-0.24^{* *}$ \\
\hline Seeds / Semillas & $-0.17^{*}$ & $0.28^{* *}$ & -0.19 & -0.95 \\
\hline Nutrition / Nutrición & $0.18^{*}$ & -.145 & $0.40^{* *}$ & .08 \\
\hline Plant health / Fitosanidad & $0.23^{* *}$ & 0.00 & $0.41^{* *}$ & -0.13 \\
\hline $\begin{array}{l}\text { Post-harvest technologies / } \\
\text { Tecnologías poscosecha }\end{array}$ & -0.06 & $0.55^{* *}$ & $-0.30^{* *}$ & -0.10 \\
\hline $\begin{array}{l}\text { Market and financing / } \\
\text { Mercado y financiamiento }\end{array}$ & 0.10 & -0.06 & $0.16^{*}$ & -0.10 \\
\hline $\begin{array}{l}\text { Organization and } \\
\text { administration / } \\
\text { Organización y administración }\end{array}$ & 0.01 & 0.16 & -0.09 & 0.04 \\
\hline $\begin{array}{l}\text { Climate effectiveness / } \\
\text { Efectividad climatológica }\end{array}$ & 0.06 & $0.33^{* *}$ & 0.04 & 0.02 \\
\hline \multicolumn{5}{|c|}{$\begin{array}{l}{ }^{*} \text { Correlation with significance level } \mathrm{P}<0.05 . \\
{ }^{* *} \text { Correlation with significance level } \mathrm{P}<0.01 \text {. } \\
\text { Source: Author-made with field information }(2016) \text {. } \\
{ }^{*} \text { Correlación con un nivel de significancia } \mathrm{P}<0.05 \text {. } \\
{ }^{* *} \text { Correlación con un nivel de significancia } \mathrm{P}<0.01 \text {. } \\
\text { Fuente: Elaboración propia con información de campo (2016). }\end{array}$} \\
\hline
\end{tabular}

and the perception of them are also known, as well as the degree of responsibility and risk that the participants are willing to assume; these are all points to be taken into account in the innovation management strategies in the territories (King et al., 2019).

\section{Conclusions}

The milpa system producers in the municipalities of the Yucatán peninsula showed a low level of adoption of innovations and a low interaction with internal and external agents in the networks. However, as a network is articulated with a balance among information source actors, there is a higher level of innovation adoption, resulting in better yields in the production units.

The yields obtained in the milpa system could be improved through appropriate innovation management strategies. In the case of the Calakmul and Maxcanú municipalities with a balanced low- una asociación directa y significativa $\quad(P<0.01)$ entre las categorías manejo agronómico, nutrición y fitosanidad con el factor externo, lo cual se explica debido a que estas categorías requieren conocimiento de tipo explícito (Nonaka y Takeuchi, 1995), es decir, conocimiento especializado, normalmente proporcionado por asesores técnicos, instituciones de enseñanza e investigación, entre otros. Con respecto al factor interno, se encontró una asociación directa y significativa $(P<0.01)$ con las categorías de semillas, tecnologías poscosecha y efectividad climatológica, esto podría explicarse debido a que las categorías llevan consigo conocimiento de tipo tácito (Nonaka y Takeuchi, 1995), un conocimiento que ha transcendido de generación en generación (Cuadro 4).

Si bien el presente estudio se centra en el análisis de las redes de innovación, la discusión presentada aquí no puede desatender otras 
density network, the strategies should focus on promoting the establishment of relationships that increase the network's density, which could be brought about through collective activities such as an exchange of experiences, workshops, and field demonstrations, among others. In the municipalities of Chikindzonot and Yaxcabá with low-density networks dominated by local actors, it is necessary, in addition to increasing the network's density, to promote the linkage with external information source actors, involving the government and teaching and research institutions present in the region. Finally, in the case of Peto, which had a dense network dominated by local actors as in previous municipalities, the inclusion of external actors is essential for the dissemination of innovations. Likewise, the innovation categories most requiring promotion are agronomic management, nutrition and plant health, due to their low adoption by producers and their positive relationship in yields.

The results show that network typologies respond to both theoretical-conceptual and practical interests. The analysis allowed verifying the causal chain between the structures of the networks with the level of innovation and yields. Therefore, the greater the interaction among the actors in a production system, the higher the level of innovation, which will be reflected in higher yields. With this information, it is possible to design specific innovation management strategies that contribute to solving problems of the productive reality.

\section{Acknowledgments}

This study is part of the "Redes de Innovación Sistema Milpa Hub Península de Yucatán 2016" project, signed between Chapingo Autonomous University (UACh) and the International Maize and Wheat Improvement Center (CIMMYT). The authors are grateful to the Yucatán Peninsula Hub staff for gathering the field information and discussing the results, as well as the milpa system producers of the Yucatán Peninsula for being so kind as to share their information for the purposes of this study.

End of English version dimensiones asociadas al concepto de capital social. Particularmente a la confianza expresada en distintas facetas, ya que es una variable que influye en los procesos de innovación, en la que también se conocen los involucrados, los recursos externos disponibles y la percepción que se tiene de ellos, así como el grado de responsabilidad y riesgo que están dispuestos a asumir los participantes, son puntos a tomar en cuenta en las estrategias de gestión de la innovación en los territorios (King et al., 2019).

\section{Conclusiones}

Los productores del sistema milpa en los municipios de la península de Yucatán mostraron un bajo nivel de adopción de innovaciones y una baja interacción con agentes internos y externos en las redes. No obstante, a medida que una red es articulada con equilibrio entre los actores fuentes de información, se presenta mayor nivel de adopción de las innovaciones, que generan a su vez mejores rendimientos en las unidades de producción.

Los rendimientos obtenidos en el sistema milpa podrían ser mejorados a partir de estrategias adecuadas de gestión de la innovación. Para el caso de los municipios Calakmul y Maxcanú con una red poco densa equilibrada, las estrategias se deben enfocar a promover el establecimiento de relaciones que aumenten la densidad de la red, esto podría darse a través de actividades colectivas cómo intercambio de experiencias, talleres, demostraciones en campo, entre otras. En los municipios Chikindzonot y Yaxcabá con redes poco densas dominadas por actores locales, es necesario, además de aumentar la densidad de la red, promover la vinculación con actores fuente de información externa, involucrando a las instituciones de gobierno y enseñanza e investigación presentes en la región. Finalmente, para el caso de Peto que tuvo una red densa dominada por actores locales al igual que en los municipios anteriores, es primordial la inclusión de actores externos para la difusión de las innovaciones. Asimismo, en todos los municipios se deben promover principalmente las categorías de innovación: manejo agronómico, nutrición y fitosanidad, debido a su baja adopción 


\section{References / Referencias}

Aguilar, Á. J. (2004). Transferencia de tecnología en la producción de granos: lecciones propuestas para México. Tesis de doctorado. Universidad Autónoma Chapingo.

Almaguer-Vargas, G., \& Ayala-Garay, A. V. (2014). Adoption of Innovations in 'Persian' Lemon (Citrus latifolia Tan.) in Tlapacoyan, Veracruz. Use of Logbook. Revista Chapingo Serie Horticultura, XX (1), 89-100. https://doi. org/10.5154/r.rchsh.2010.10.076

Borgatti, S. P., Everett, M. G., \& Freeman, L. C. (2002). Ucinet for Windows: Software for Social Network Analysis. Analytic Technologies. Disponible en: citeulike-article-id:6031268.

Bourdieu, P. (1980). Le capital social: Notes provisoires. Actes de la recherche en sciences sociales, 31, 2-3.

Cofré-Bravo, G., Klerkx, L., \& Engler, A. (2019). Combinations of bonding, bridging, and linking social capital for farm innovation: How farmers con fi gure di ff erent support networks. Journal of Rural Studies. 69, 53-64. https://doi. org/10.1016/j.jrurstud.2019.04.004

Coleman, J. S. (1988). Social Capital in the Creation of Human Capital. American Journal of Sociology, 94, S95S120. https://doi.org/10.1086/228943.

Corsaro, D., Cantú, C., \& Tunisini, A. (2012). Actors' Heterogeneity in Innovation Networks. Industrial Marketing Management, 41(5), 780-789. https://doi. org/10.1016/j.indmarman.2012.06.005

Cotec. (2001). Innovación Tecnológica. Ideas Básicas. (Revilla Gutiérrez, E. Ed.). Madrid: Gráficas Arias Montano, S. A. $46 \mathrm{p}$.

Cotec. (2007). La Persona Protagonista de la Innovación. (Gráficas Arias M., S. A. Ed.). Madrid.143 p.

Dosi, G., Teece, D., \& Chytry, J. (1998). Technology, organization, and competitiveness: perspectives on industrial and corporate change and competitiveness. Disponible en: http://scholar.google.com/scholar?hl= en\&btnG=Search\&q=intitle:Technology,+organizatio n,+and+competitiveness\#3\%5Cnhttp://econpapers. repec.org/RePEc:oxp:obooks:9780198290964

Freeman, L. C. (2004). The Development of Social Network Analysis: A study in the sociology of Science. Vancouver: Empircal Press. $218 \mathrm{p}$.

García, E. I., Aguilar, J., \& Bernal, R. (2011). La Agricultura Protegida en Tlaxcala, México. Teuken Bidikay, 2, 193-212.

Gómez, M. E. (2013). Los milperos tradicionales de Chiapas: sujetos del desarrollo frente a la crisis del sistema agroalimentario. Tesis de doctorado. Universidad Autónoma Metropolitana. por los productores y por su relación positiva en los rendimientos.

Los resultados evidencian que las tipologías de redes responden a los intereses teórico-conceptuales y también prácticos. El análisis permitió verificar la cadena causal entre las estructuras de las redes con el nivel de innovación y los rendimientos. Por lo que entre mayor interacción exista entre los actores de un sistema de producción, mayor será el nivel de innovación, lo cual se reflejará en mayores rendimientos. Con esta información se posibilita el diseño de estrategias de gestión de la innovación específicas que contribuyan a resolver problemáticas de la realidad productiva.

\section{Agradecimientos}

Este estudio forma parte del Proyecto "Redes de Innovación Sistema Milpa Hub Península de Yucatán 2016", celebrado entre la Universidad Autónoma Chapingo (UACh) y el Centro Internacional de Mejoramiento de Maíz y Trigo (CIMMYT). Se agradece la participación del personal del Hub Península Yucatán en el levantamiento de la información de campo y la discusión de los resultados. Así como a los productores del sistema milpa de la península de Yucatán por ser tan amables de compartir su información para llevar acabo el presente estudio.

Fin de la versión en español

Islas, M. A., \& Rendón, M. (2019). Difusión de innovaciones en sistemas pecuarios de especialidad: empresas productoras de avestruz en México. RIVAR, 6(17), 15-26.

King, B., Fielke, S., Bayne, K., Klerkx, L., \& Nettle, R. (2019). Navigating shades of social capital and trust to leverage opportunities for rural innovation. Journal of Rural Studies, 68, 123-134. https://doi.org/10.1016/j. jrurstud.2019.02.003

Klerkx, L., Aarts, N., \& Leeuwis, C. (2010). Adaptive management in agricultural innovation systems: The interactions between innovation networks and their environment. Agricultural Systems, 103, 390-400. https://doi.org/10.1016/j.agsy.2010.03.012 
Monge, P. M., \& Hartwich, F. (2008). Análisis de Redes Sociales aplicado al estudio de los procesos de innovación agrícola. REDES-Revista Hispana para el Análisis de Redes Sociales, 14(2), 1-31.

Muñoz, R. M., Rendón, R., Aguilar, J., García, J. G., \& Altamirano J., R. (2004). Redes de Innovación. Un acercamiento a su identificación, análisis y gestión para el Desarrollo Rural (1a ed.). Michoacán, México. Fundación Produce Michoacán/ Universidad Autónoma Chapingo.134 p.

Muñoz, R. M., Aguilar, J., Rendón, R., \& Altamirano, J. R. (2007). Análisis de la dinámica de innovación en cadenas agroalimentarias. Serie: Materiales de formación para las Agencias de Gestión de la Innovación. Universidad Autónoma Chapingo-CIESTAAM/PIIAI.71 p.

Nelson, R. R., \& Winter, G. (1982). An evolutionary theory of economic change. The Economic Journal. 93. https:// doi.org/10.2307/2232409.

Nonaka, I., \& Takeuchi, H. (1995). The Knowledge-Creating Company. How Japanese Companies Create the Dynamics of Innovation. New York: Oxford University Press. 304 p.

Poder, T. G. (2011). What is Really Social Capital? A Critical Review. American Sociologist, 42(4), 341-367. https://doi. org/10.1007/s12108-011-9136-z.

Putnam, R. D. (1995). Bowling alone: America's declining social capital. Journal of Democracy, 6(1), 65-78.

Radjou, N. (2004). Innovation networks. A new market structure will revitalize invention-to-innovation cycles. Forrester Big Idea, 1-20.

Rendón, M. R., Aguilar, J., Altamirano, J. R., \& Muñoz, M. (2007). Etapas del mapeo de redes territoriales de innovación (19 ed). Universidad Autónoma Chapingo.45 p. México.

Roldán-Suárez, E., Rendón-Medel, R., \& Cadena-Íñiguez, P. (2016). Identificación de Módulos Demostrativos en Estrategias de Gestión de la Innovación. Agricultura, Sociedad y Desarrollo. 13(2), 179-192. Disponible en: http://www.colpos.mx/asyd/revista.php?v=13\&n=2
Salazar, B. L., \& Magaña, M. Á. (2016). Aportación de la milpa y traspatio a la autosuficiencia alimentaria en comunidades mayas de Yucatán. Estudios Sociales. 24(47), 182-203.

Sánchez, G. J., Rendón, R., Díaz, J., \& Sonder, K. (2016). El Soporte Institucional en la Adopción de Innovaciones del Productor de Maíz: Región Centro, México. Revista Mexicana de Ciencias Agrícolas, (15), 2925-2938. Disponible en: http://cienciasagricolas.inifap.gob.mx/ index.php/es/282-rss/3965-el-soporte-institucionalen-la-adopcion-de-innovaciones-del-productor-demaiz-region-centro-mexico

Schumpeter, J. A. (1942). Capitalism, Socialism and Democracy. (T. y F. E-Library, Ed.). George Allen \& Unwin.437p.

Schwartz, N. B., \& Corzo A., R. (2015). Swidden Counts: A Petén, Guatemala, Milpa System. Production, Carrying Capacity, and Sustainability in the Southern Maya Lowlands. Journal of Anthropological Research, 71(1), 69-93.

Terán, C. S. (2010). Milpa, biodiversidad y diversidad cultural. In Biodiversidad y Desarrollo Humano en Yucatán. Capítulo 2. El Estado (pp. 54-56). CICY, PPDFMAM, CONABIO, SEDUMA.

Vargas C., J. M., Palacios, I., Camacho, J., Aguilar, J., \& Ocampo J., G. (2015). Factores de innovación en agricultura protegida en la región de Tulancingo, México. Revista Mexicana de Ciencias Agrícolas, 6(4), 827-840.

Wasserman, S., \& Faust, K. (1994). Social Network Analysis. Methods and Applications. (M. S. Granovetter, Ed.). Estados Unidos de América: Cambridge University Press. 819p.

Wójcik, M., Jeziorska-Biel, P., \& Czapiewski, K. (2019). Between words: A generational discussion about farming knowledge sources. Journal of Rural Studies, 67, 130-141. https://doi.org/10.1016/j.jrurstud.2019.02.024. 


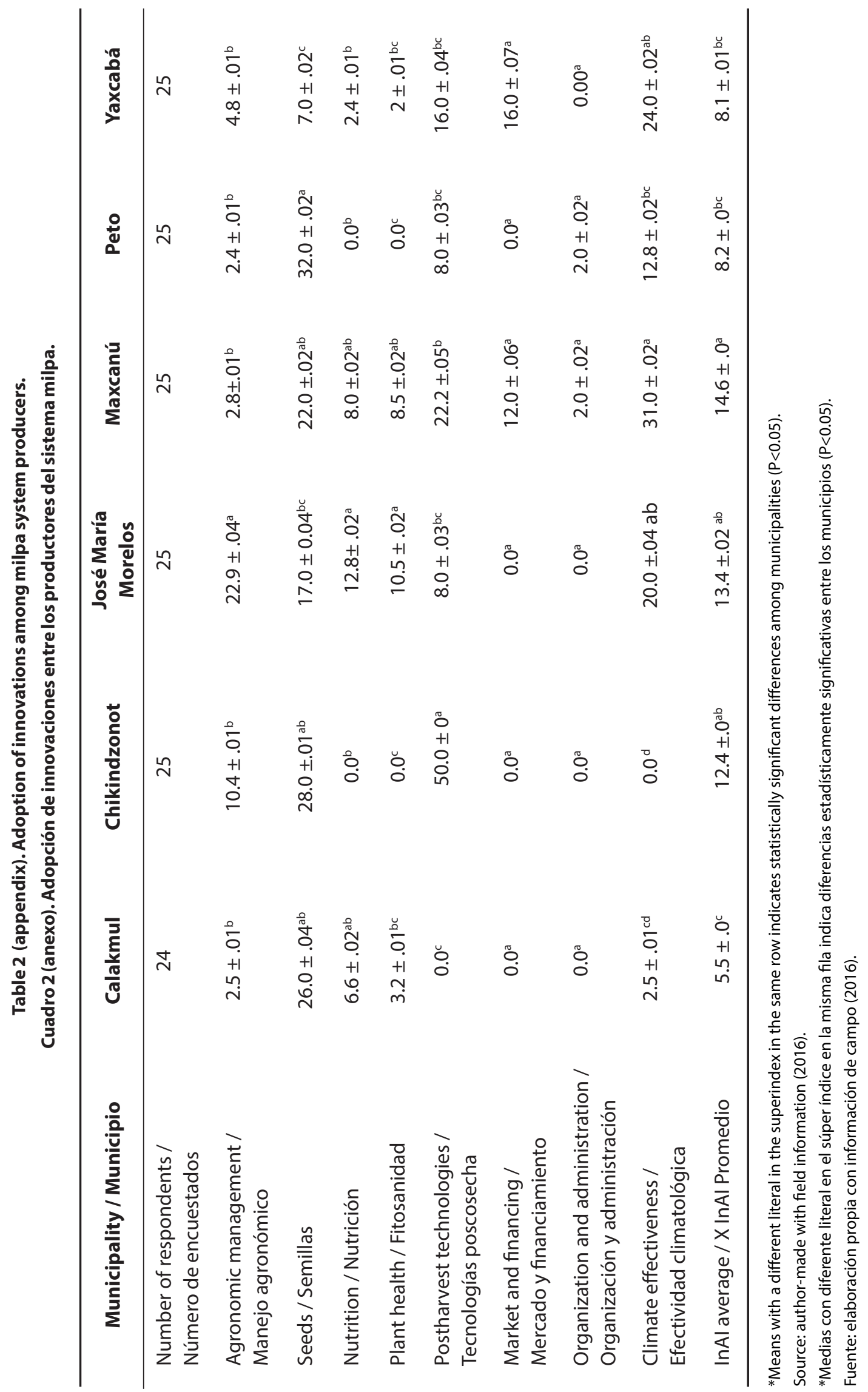

